\title{
Tax Revenue Effort in Nigeria
}

\author{
Jude Ohi Ikhatua ${ }^{1} \&$ Peter Okoeguale Ibadin ${ }^{1}$ \\ ${ }^{1}$ Department of Accounting, Faculty of Management Sciences, University of Benin, Nigeria. \\ Correspondence: Peter Okoeguale Ibadin, Department of Accounting, Faculty of Management Sciences, University \\ of Benin, Nigeria. E-mail: ohiorenuan.ikhatua@ uniben.edu \& okoeguale.ibadin@uniben.edu
}

Received: December 10, 2018

Accepted: January 2, 2019

Online Published: January 14, 2019

doi:10.5430/afr.v8n1p103

URL: https://doi.org/10.5430/afr.v8n1p103

\begin{abstract}
Today, countries, especially the developing ones rebase their Gross Domestic Product (GDP) to determine their economic strength. Nigeria as an acclaimed giant in Africa cannot but continuously examine variables which may impact the economy. It is in this light that this study was intended to investigate the Determinants of Tax Revenue Effort in Nigeria. To achieve this, secondary data, as time series data, covering a period of 1980 to 2015, were used and sourced from the Central Bank of Nigeria Statistical Bulletin, Annual Abstract from the Office of the National Bureau of Statistics and the Federal Inland Revenue Service, both in Nigeria. The dependent variable of Tax Revenue Effort (TTAXeff) was regressed on macro independent variables of Agricultural Sector Productivity(AGRICSP), Manufacturing Sector Productivity (MANSP), Tourism Sector Productivity(TOURSP), Telecommunication Sector Productivity(TELCOMSP), Capital Flight(CAPFR), Trade Openness (TOPEN) and Human Capital Development(HCD). The study adopted a longitudinal research design and used the Autoregressive Distributed Lag (ARDL) technique to evaluate the models. The findings revealed that Agricultural Sector Productivity, Tourism Sector Productivity, Trade Openness and Human Capital Development had significant and positive effects on Tax Revenue Effort in Nigeria. The Manufacturing Sector Productivity, Telecommunication Sector Productivity and Capital Flight had significant but negative effects on Tax Revenue Effort in Nigeria. There is however the need to consistently ensure better performance of tax efforts in the country through strict and meticulous enforcement of tax rules and tax administrations procedures in the country.
\end{abstract}

Keywords: tax revenue effort, determinants, Nigeria

\section{Introduction}

Countries nowadays tend to focus more seriously on domestic resource mobilization in order to provide enough resources for development purposes. And a key objective of this domestic resource mobilization is to increase tax revenue effort. Defined simply, tax revenue effort is a ratio that assesses the level of tax collection effort of a country. Such a ratio represents tax collection to Gross Domestic Product (GDP); and it is often used to establish patterns and trends of tax collection effort.

According to PriceWaterhouse Cooper (2014), Nigeria's tax revenue effort of 3\% was one of the lowest in the world when compared to the United States' tax revenue effort which was 19\%, China, 21\%, Japan, 35\%, Germany, 45\%, and France, $52 \%$. In Africa, Ghana's tax revenue to GDP is $22 \%$, South Africa, $27 \%$ and Kenya, $17 \%$. Nigeria's poor ratio of 3\% can be traced to the country's over-dependence on oil with the result that less emphasis is placed on tax to the point that Nigerian tax revenue effort lags behind the World Bank's benchmark of $15 \%$ (Muthui, Akims, Mdoe, \&Thuku, 2015).

Prior studies on tax revenue effort, such as the studies by Karagoz (2013); Babyenda and Klege (2014); Ayenew (2015); Gaalya (2015); Brun and Diakite (2016), revealed a very limited coverage of the potential of the non-oil, sectors in improving tax revenue effort. The sectors considered by these studies were predominantly the Agricultural and the Manufacturing sectors. Also, with the exception of few studies such as Urhoghide and Asemota (2013); Ayenew (2015); and Murunga, Muritthi and Kiiru (2016), most previous researches on tax revenue effort were carried out on a cross country basis!

Langford and Ohlenburg (2015) have argued that a cross country study presents some difficulties in controlling for country specific factors in data comparability. This therefore creates a limitation to these studies. Another very important issue in the tax revenue effort literature is the limited consideration of the impact capital flight has on it. In developing countries, capital flight hinders the internal effort of government to raise revenue as it disrupts the tax 
bases that are essential to stimulating tax revenue efforts.It is seen as one of the greatest avenue through which capital is shipped away from developing countries, such as Nigeria (African Development Bank [AfDB] \& Global Financial Integrity [GFI], 2013; Henry, 2012 and Ndikumana \& Boyce, 2011).

It is against this background that this study adds to the corpus of the growing literature on the determinants of tax revenue effort in Nigeria. To this end, the main objective of this study is to examine the determinants of tax revenue effort in Nigeria, with a focus on factors that can impinge on the tax revenue effort in Nigeria.

\section{Literature Review}

Tax revenue effort was first muted in 1967 by Lotz and Morss while studying international tax ratio. It is defined as the ratio of tax revenue to gross domestic product (Piancastelli, 2001). This ratio measures the tax revenue collected by the government in relation to the gross domestic product. Langford and Ohlenburg (2015) however describe tax revenue effort as the tax potential, and the maximum amount of tax a country could hope to raise at a given point in time; it is the extent to which actual tax revenue reaches estimated capacity. This potential is a function of economic factors, amongst which are the following macro factors which are examined in no particular order.

\subsection{Agricultural Sector Productivity and Tax Revenue Effort}

All over the world, agriculture is carried out either for individual or commercial purposes. In a developing country like Nigeria, there is difficulty in taxing the rural sector which mainly consists of subsistent farmers who sell their products in unorganized markets (Stotsky \&Woldermian, 1997). However, over the years, the contribution of the agricultural sector to Gross Domestic Product (GDP) cannot be over-emphasized. The Central Bank of Nigeria (2012) showed that the contribution of agriculture to GDP was very significant despite the declining productivity of the sector. In 1985, it contributed $40.9 \%$ to GDP, in 1990 it was $39.0 \%$, and $41 \%$ in 2000 . The period covering 2000 to 2004 recorded an average of $40 \%$ while in 2006, it contributed $41.8 \%$ to GDP. It is however, very sad that presently, according to (World Development Indicator, 2014) the agricultural sector now accounts for less than $30 \%$ of the nation's GDP.

Generally, the agricultural sector is expected to have a negative effect on tax ratio, that is, it naturally has a significant impact on tax ratio, though negatively. It is not surprising, therefore, that many cross country studies find a negative relationship between agriculture's share in GDP and tax revenue effort. Gaalya (2015) studied trade liberalization and tax revenue performance in Uganda, covering 1994 to 2012 period. Using ordinary least square regression for data analysis, he found that agriculture's share in GDP had a negative influence on tax performance in Uganda. Brun and Diakite (2016) studied tax potential and tax effort of a large sample of developing countries over a period of 30 years covering 1984 to 2014. Using the two stage least square technique to estimate the data, they found that agriculture's value added had a negative and significant relationship with tax revenue effort.

However, some researchers have found agriculture's share in GDP to have a positive effect on tax revenue effort. Mahdavi (2008) studied the level of composition of tax revenue in 43 developing countries including Pakistan for the period of 1973 to 2002. Using advanced estimation techniques and an unbalanced panel data set, he discovered that agriculture sector's share in GDP showed a positive but an insignificant relationship. Also, Murunga, Muritthi and Kiiru (2016), while studying the tax effort and the determinants of tax ratio in Kenya between 1980 and 2015, found the share of agriculture to be positively related to tax revenue effort. Ahsan and Wu (2005) investigated the determinants of the share of tax revenue in GDP for developing and developed countries using panel research method. The study found that the coefficient of share of agriculture in GDP was positive and significant.

\subsection{Manufacturing Sector Productivity and Tax Revenue Effort}

The manufacturing sector refers to a portion of an economy that consists of industries involved in the processing and manufacturing of goods which give free rein to either the creation of new commodities or value addition (Adebayo, 2010). The sector involves value creation at the level of raw materials to finished products (Mbelede, 2012). But in recent years, the productivity levels of some of the manufacturing industries have really dropped (Eze \& Ogiji, 2013). This has been traced to the import-dependency of the economy. A look at the manufacturing sector's share in GDP showed that in the 1990s, it was 5.5\%; in 2000, it was 3.7\%; in 2010, it became $6.5 \%$, and in 2014 it was $9.8 \%$ (World Development Indicator, 2015). Okafor (2012) argued that the level of Nigerian manufacturing industries' performance would continue to fluctuate as a result of the low implementation of government budget and difficulty in assessing raw materials suggesting that the relationship between the manufacturing sector and tax revenue performance was expected to be negative. However,Piancastelli (2001), while measuring the tax effort of developed and developing countries and utilizing cross sectional regression and panel data analyses, discovered that the share of manufacturing in GDP was positively related to tax revenue effort. 
Babyenda and Klege (2014) studied the East African Community and Ugandan tax revenue. They carried out this study using Johansen's co-integration procedure and error correction models for data analysis. Data for a period of 31 years, spanning 1980 to 2011, were used and the estimation revealed that manufacturing share in GDP positively influenced Ugandan tax revenue. Oyetunji (2012) studied the determinants of tax revenue in Nigeria covering the period between 1986 and 2010. Using vector auto regression models for data analysis, he found that manufacturing sector GDP was positive and significantly related to tax revenue. The positive relationship was because owners of manufacturing companies tended to keep better books and followed better accounting practices, and the manufacturing sector tended to generate larger taxable revenue than the agricultural sector (Eltony, 2002). However, Teera and Hudson (2004), in their study covering 120 developing and developed countries for period 1975 to 1998 grouped the countries into high, middle and low income countries, and found the ratio of manufacturing share to GDP to be significant and negative for middle income countries suggesting that the level of industrialization in those middle income countries was very low.

\subsection{Tourism Sector Productivity and Tax Revenue Effort}

Mathieson and Wall (1982) explained tourism to be the temporary movement of people to destinations outside their normal places of residence and work, where the facilities to take care of their needs and the activities undertaken during their stay in those destinations were all created. The recent publication of the World Travel and Tourism Council of 2014 (WTTC, 2014) showed that in 2013, travel and tourism's total contribution to the global economy rose to US\$7 trillion, about 9.5 per cent of global GDP, not only outpacing the wider economy but also growing faster than other significant sectors such as financial and business services, transport and manufacturing, and its total contribution to employment creating nearly 266 million jobs, about 8.9 percent of world employment. Recognizing these facts, many developing and developed countries today rely on tourism as an option for sustainable development of their nations.

Tourism today has become a very important sector in the Nigerian economy with a contribution of 3.20 per cent to national Gross Domestic Product (GDP) and providing 2.70 per cent of total employment in 2013 (WTTC, 2014). Tourism industry's contribution to GDP, according to World Travel and Tourism Council (WTTC), was envisaged to rise by 1.9 per cent in 2014 and 6.1 per cent per annum from 2014 to 2024. The Nigerian tourism sector is therefore, growing and it is capable of generating employment and earning a large amount of foreign exchange that rivals agriculture and petroleum sectors. Despite tourism's increasing importance to the Nigerian economy, it has attracted limited empirical research.

From the extant literature, the relationship between the service sector and tax revenue has been mixed. A study by Murunga, Muritthi and Kiiru (2016) on the tax effort and the determinants of tax ratio in Kenya between 1980 and 2015 found share of service sector to be positively related to tax revenue effort. Also Ahmed and Mohammed (2010) examined the determinants of tax buoyancy in 25 developing countries. Utilising the pooled least square method for data analysis on data covering 1998 to 2008, he discovered that the service sector showed a positive significant effect on tax buoyancy. However, Bothole (2010) in his study on the tax effort and the determinants of tax ratio in Sub-Saharan Africa covering 1990 to 2006.while utilising the two stage least square technique and the generalized method of moments, discovered that services share in GDP was detrimental to tax ratio.

\subsection{Telecommunication Sector Productivity and Tax Revenue Effort}

Telecommunication is recognized world-over as an important tool for the socio-economic development for a nation, and it plays a phenomenal role in the growth and modernization of various sectors of the economy.

The telecommunication sector is very important in the development of a modern country as it leads to the attainment of improved industrialization and hence improved tax revenue effort. In 2014, the Nigerian Communication Commission (NCC, 2014) released statistics which showed that the telecommunication sector greatly contributed to GDP as its contribution increased from $0.62 \%$ in 2001 to $8.53 \%$ in 2013. A further look at the statistics revealed that the sector paid close to N400 billion in taxes in 2012, and the various network providers paid about N55 billion as regulatory levies and N160 billion in taxes yearly (Ogunsanya, 2013). With an expansion in the industrial sector, the increase in sales and consumption taxes would usually be more than the increase in per capita income. With this in mind, it could be said that tax revenue effort could be higher in the countries where industrial and service sector are more developed. Murunga, Muritthi and Kiiru (2016), while studying the tax effort and the determinants of tax ratio in Kenya between 1980 and 2015, found share of service sector to be positively related to tax revenue effort. However, Bothole (2010) discovered that services share in GDP was detrimental to tax ratio. 


\subsection{Capital Flight and Tax Revenue Effort}

Capital flight refers to international capital movements which respond to a variety of factors such as heightened domestic economic and political uncertainty, the need for tax shelters, safe havens and a means for illegal diversion of funds (Uguru, 2016). According to Ajayi (1997), there had been an increased spread of currency speculation and the unprecedented movement of foreign private capital out of developing countries which was attributed to a large balance of payment and globalization. Uguru (2016) observed, that transfer mispricing was one of the largest means of diverting capital out of Nigeria, that is, transfer mispricing activities that mainly involved money laundering and tax evasion by corporate actors. Transfer pricing and tax heavens are some mechanisms through which multinational companies practice capital flight.

Isu (2002) studied the implication of capital flight on the development of Nigeria covering 1970-1991and discovered that Nigeria had lost resources in excess of $\$ 45$ billion to capital flight thus indicating that capital flight had a negative impact on internal resource mobilization. Saheed and Ayodeji (2010) examined the impact of capital flight on exchange rate and economic growth in Nigeria. Utilizing the ordinary least square regression technique for data analysis, they discovered that the impact capital flight had on exchange rate was positive and significant, and that unlike most studies, capital flight influenced Nigeria's economic growth positively. Uguru (2011), while studying the impact of capital flight on taxes paid by some selected multinational corporations in Nigeria, discovered that capital flight through tax evasion reduced government revenue and in turn affected tax revenue effort. Also, Uguru (2016), in his study of the effect of capital flight on tax revenue in Nigeria, found that capital flight had a significant effect on tax revenue as a percentage increase in capital flight led to a two percent decrease in tax revenue.

\subsection{Trade Openness and Tax Revenue Effort}

Trade openness is a trade policy which encourages the unhindered flow of goods and services by government-imposed restrictions. It is the summation or totality of export and import levels as a fraction of GDP (Le, Moreno-Dodson and Bayraktar, 2012). It involves the consolidation and relaxation of tariff rates by advancing the export level and exchange rate depreciation (Rajaram, 1994).Tax revenue effort and trade openness has various relationships in literature.

Urhoghide and Asemota (2013), while studying the determinants of tax revenue effort evidence from Nigeria from 1985 to 2011, and utilizing multivariate co-integration and error correction models, discovered that there was a positive relationship between openness of the economy and tax revenue effort. Gaalya (2015) studied trade liberalization and tax revenue performance in Uganda from 1994 to 2012. Using ordinary least square regression for data analysis, he discovered that trade openness had a significant effect on tax revenue performance in Uganda. Brun and Diakite (2016) studied tax potential and tax effort of a large sample of developing countries over a period of 30 years covering 1984 to 2014. Using the two stage least square technique to estimate the data, they found that trade openness was significantly and positively related to tax revenue effort. This could be so because, as opined by Alonso and

However, Bird, Martinez-Vasquez and Torgler (2004) carried out a study using 110 developing countries from 1990 to 1999. The findings revealed that trade openness showed a negative significance. Rabei and Balagetabi (2013) studied the tax capacity and effort of six Organization of Petroleum Exporting Countries (OPEC) member countries: Iran, Kuwait, United Arab Emirates, Venezuela, Argentina and Saudi Arabia and their relationship with oil revenue. Using the hausman's test to confirm the estimation of the panel data that was estimated with fixed effect method, their findings revealed that openness of the economy had a significant negative effect.

\subsection{Human Capital Development and Tax Revenue Effort}

A rise in the degree of human capital is related to a rise in tax ratio (Andreoni, Erard, \& Feinstein, 1998). The level of knowledge and understanding ought to be a crucial determinant in the manner tax-payers act. More knowledgeable tax payers are expected to know about tax laws and fiscal relationships such that it becomes easier to mobilize tax revenue.

Mahdavi (2008) studied the level of composition of tax revenue in 43 developing countries, covering a period of 1970 to 2002.The findings from the study showed that a higher level of basic education and a good literacy rate ultimately increased tax revenue. However, Chaudry and Munir (2010), while analyzing the determinants of low tax revenue in Pakistan discovered that an increase in the literacy rate brought about a decrease in the collected tax revenue. 


\subsection{Review of Related Theories}

This study was anchored on the theory of tax structure development as advanced by Hinricks (1966).This theory explains the connection between the economic structure and nature of tax base as well as the availability of tax bases to raise revenue. In developed and developing countries of the world, tax system crosses through series of stages in the economic development process. (Hinricks, 1966; and Musgrave, 1969). Economic development is said to have a tough effect on the tax base of a country's economy. The theory recommends that at the prior stages of economic development, the economic structure charges harsh restrictions on the structure of the system. Hence, there is a great level of tax avoidance and evasion. Furthermore, taxes are difficult to collect due to the absence of the machinery for tax collection and administration (Hinricks, 1966). Majority of countries with low incomes also suffer from low tax collection and low tax effort. Low tax collection indicates that tax revenue collected is below its potential. As economic development strides forward and the economic structure grows, new opportunities spring up for countries to promote their tax revenue effort. At this stage, the attainable taxable capacity of a state relies not just on income but on controlled factors like the level of consumption, variations in price, structural composition of the economy, income distribution etc (Bird et al, 2008).

\section{Methodology and Data}

The study adopts a longitudinal research design. The choice of this design was made in order to have an established trend. To this end, the longitudinal timeframe was 1980 to 2015. Secondary data was used, and collected from the Central bank of Nigeria's (2013,2014 (CBN's) statistical bulletin, the Office of the Federal Inland Revenue Service(2014,2015), National Bureau of Statistics'(2014,2015) Annual Abstracts of Statistics. The data were analyzed, using the Autoregressive Distributed Lag (ARDL) model approach to Co-integration. The utility of Autoregressive Distributed Lag (ARDL) model approach to Co-integration lies in its application on long term series irrespective of whether the series are stationary at levels $\{1(0)\}$ or at first order $\{1(1)\}$; and it is used to test for the existence of a linear long-run relationship when the order of integration of the underlying regressors is not known with certainty(Pesaran,Shin ,\& Smith,1996,2001). However, the analyses was preceded by several diagnostic tests, such as; normality test, stationary test and multicolinearity test. The model for this study ultimately reflected a form that showed the relationship between the variables and the theories.

\subsection{Model Specification}

The functional model used is:

$$
T_{T A X} X_{\text {eff }}=f \text { (AGRICSP, MANSP, TOURSP, TELECOMP, CAPFR, TOPEN HCD) }
$$

Equation (1) is transformed into econometric form as;

$$
\begin{array}{r}
\text { TTAX }_{\text {eff }}=\beta o+\beta_{1} \text { AGRICSP }_{t}+\beta_{2} \text { MANSP }_{t}+\beta_{3} \text { TOURSP }_{t}+\beta_{4} \text { TELCOMSP }_{t}+\beta_{5} \text { CAPFR }_{t} \\
+\beta_{6} \text { TOPEN }_{t}+\beta_{7} \text { HCD }_{t}+U_{t} \ldots \ldots \ldots \ldots \ldots \ldots \ldots \ldots \ldots \ldots \ldots \ldots \ldots \ldots \ldots \ldots \ldots \ldots
\end{array}
$$

For a more robust consideration equation (v) is further decomposed into direct tax revenue effort as:

$$
\begin{aligned}
D T_{\text {eff }}=\beta o+\beta_{1} \text { AGRICSP }_{t}+\beta_{2} \text { MANSP }_{t} & +\beta_{3} \text { TOURSP }_{t}+\beta_{4} \text { TELCOMSP }_{t}+\beta_{5} C A P F R_{t} \\
& +\beta_{6} \text { TOPEN }_{t}+\beta_{7} \text { HCD }_{t}+U_{t} \ldots \ldots \ldots \ldots \ldots \ldots \ldots \ldots \ldots \ldots \ldots \ldots \ldots \ldots
\end{aligned}
$$

Indirect tax revenue effort as:

$$
\begin{aligned}
& I N D T_{\text {eff }}=\beta o+\beta_{1} \text { AGRICSP }_{t}+\beta_{2} \text { MANSP }_{t}+\beta_{3} \text { TOURSP }_{t}+\beta_{4} \text { TELCOMSP }_{t}+\beta_{5} \text { CAPFR }_{t} \\
& +\beta_{6} \text { TOPEN }_{t}+\beta_{9} H C D_{t}+U_{t}
\end{aligned}
$$

And non-oil tax revenue effort as:

$$
\begin{aligned}
\text { NOT }_{\text {eff }}=\beta O+\beta_{1} \text { AGRICSP }_{t}+\beta_{2} \text { MANSP }_{t} & +\beta_{3} \text { TOURSP }_{t}+\beta_{4} \text { TELCOMSP }_{t}+\beta_{5} \text { CAPFR }_{t} \\
& +\beta_{6} \text { TOPEN }_{t}+\beta_{9} \text { HCD }_{t}+U_{t} \ldots \ldots \ldots \ldots \ldots \ldots \ldots \ldots \ldots \ldots \ldots \ldots \ldots \ldots
\end{aligned}
$$

Where; $T T A X_{\text {eff }}=$ Total tax revenue effort, $D T_{\text {eff }}=$ Direct tax revenue effort, INDT $T_{\text {eff }}=$ Indirect tax revenue effort, $N O T_{\text {eff }}=$ Non-oil tax revenue effort, $A G R I C S P_{t}=$ Agricultural sector Productivity, MANSP $_{t}=$ Manufacturing sector Productivity, TOURSP $_{t}=$ Tourism sector productivity, TELCOMSP ${ }_{t}=$ Telecommunications sector Productivity, $C A P F R_{t}=$ Capital flight TOPEN $N_{t}=$ Trade Openness, $H C D_{t}=$ Human capital development,$U_{t i}=$ Error term

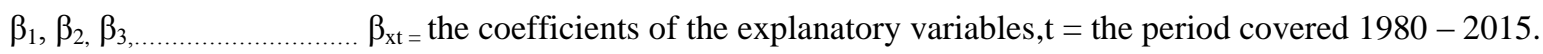

Aprior expectation: From extant literature, we expect the explanatory variables to increase tax revenue effort. 
Therefore, we presumptively expect; $\beta_{1}, \beta_{2}, \beta_{3, \ldots \ldots . .} \beta_{x t}>0, \beta_{4}$

Table 1. Operationalization of variables

\begin{tabular}{|c|c|c|c|}
\hline Variable & Measurement & Source & Apriori Sign \\
\hline Total tax revenue effort & Ratio of Total tax to GDP & $\begin{array}{lr}\text { Bird, } & \text { Jorge } \\
\text { Martinez-Vazquez } & \text { and } \\
\text { Torgler (2008), } & \text { Ndiaye } \\
\text { and Korsu (2011) } & \end{array}$ & \\
\hline Direct tax revenue effort & Ratio of direct tax to GDP & Ndiaye and Korsu (2011) & \\
\hline Indirect tax revenue effort & Ratio of direct tax to GDP & Ndiaye and Korsu (2011) & \\
\hline Non-oil tax revenue effort & $\begin{array}{l}\text { Ratio of non-oil tax to } \\
\text { GDP }\end{array}$ & & \\
\hline $\begin{array}{l}\text { Agricultural } \\
\text { productivity }\end{array}$ & $\begin{array}{l}\text { Ratio of Agric sector GDP } \\
\text { to total GDP }\end{array}$ & $\begin{array}{l}\text { Piancastelli } \\
\text { Bothole }(2010)\end{array}$ & + \\
\hline $\begin{array}{l}\text { Manufacturing } \\
\text { productivity }\end{array}$ & $\begin{array}{l}\text { Ratio of manufacturing } \\
\text { sector GDP to total GDP }\end{array}$ & $\begin{array}{l}\text { Chaudhry and Munir } \\
(2010) ; \quad \text { Babyenda and } \\
\text { Klege }(2014)\end{array}$ & + \\
\hline $\begin{array}{l}\text { Tourism } \\
\text { productivity }\end{array}$ & $\begin{array}{l}\text { Ratio of Tourism sector } \\
\text { GDP to total GDP }\end{array}$ & $\begin{array}{l}\text { Chaudhry and Munir } \\
(2010) \text {; Karagoz (2013) }\end{array}$ & + \\
\hline $\begin{array}{l}\text { Telecommunications } \\
\text { sector productivity }\end{array}$ & $\begin{array}{l}\text { Ratio of telecoms. sector } \\
\text { GDP to total GDP }\end{array}$ & $\begin{array}{l}\text { Chaudhry and Munir } \\
\text { (2010); Karagoz (2013) }\end{array}$ & + \\
\hline Capital flight & $\begin{array}{l}\text { Determined based on the } \\
\text { residual approach. } \\
\text { Computed as: } \triangle \mathrm{DEBT}+ \\
\text { FDI - }(\mathrm{CA}-\mathrm{RES})\end{array}$ & $\begin{array}{l}\text { Schneider (2003);Boyce } \\
\text { and Ndikumana (2012) }\end{array}$ & - \\
\hline & $\begin{array}{l}\text { Where } \triangle \mathrm{DEBT}=\text { change } \\
\text { in total external debt stock }\end{array}$ & & \\
\hline & $\begin{array}{l}\text { FDI = foreign direct } \\
\text { investment }\end{array}$ & & \\
\hline & $\begin{array}{l}\mathrm{CA}=\text { current account } \\
\text { deficit in the Balance of } \\
\text { Payment }\end{array}$ & & \\
\hline & RES = foreign reserves & & \\
\hline Trade Openness & $\begin{array}{l}\text { Import }+ \text { exports divided } \\
\text { by GDP }\end{array}$ & $\begin{array}{l}\text { Agbeyegbea, Stotskyb and } \\
\text { WoldeMariam (2004); } \\
\text { Davoodi and Grigorian, } \\
(2007)\end{array}$ & + \\
\hline $\begin{array}{l}\text { Human } \\
\text { development }\end{array}$ & $\begin{array}{l}\text { Secondary } \\
\text { enrolment rate }\end{array}$ & $\begin{array}{l}\text { Anyanwu, Adam, Obi and } \\
\text { Yelwa (2015) }\end{array}$ & + \\
\hline
\end{tabular}

\section{Source: Researcher, 2017}

\section{Presentation and Analysis of Result}

The descriptive and inferential statistics are presented in the following sections of this study 


\subsection{Descriptive Statistics}

Table 2. Descriptive statistics

\begin{tabular}{lllllllll}
\hline & Mean & Max. & Min & SD & Skew & Kurt & J-B & Probability \\
\hline TTAX eff & 11.44 & 22.92 & 4.23 & 17.97 & 5.35 & 30.77 & 4.74 & 0.019 \\
DTeff & 6.74 & 31.59 & 1.99 & 5.30 & 3.10 & 14.90 & 262.35 & 0 \\
INDTeff & 2.51 & 3.49 & 1.77 & 0.47 & 0.48 & 2.49 & 1.73 & 0.042 \\
NOTeff & 3.23 & 5.38 & 2.02 & 0.89 & 0.69 & 2.46 & 3.22 & 0.020 \\
AGRICSP & 21.16 & 26.99 & 15.50 & 3.22 & 0.23 & 1.84 & 2.26 & 0.032 \\
MANSP & 7.98 & 11.78 & 6.05 & 1.50 & 0.44 & 2.26 & 1.93 & 0.038 \\
TELECOMSP & 2.45 & 9.03 & 0.08 & 3.37 & 1.05 & 2.42 & 6.97 & 0.03 \\
TOURSP & 0.33 & 0.95 & 0.16 & 0.21 & 1.86 & 5.81 & 31.70 & 0 \\
CAPFR & -19.36 & 102.87 & -19.40 & 63.88 & -1.37 & 4.57 & 14.57 & 0.00 \\
TOPEN & 30.91 & 58.92 & 7.36 & 12.88 & -0.17 & 2.37 & 0.75 & 0.049 \\
HCD & 67.32 & 39.33 & 16.83 & 5.24 & 0.54 & 2.54 & 2.00 & 0.037 \\
\hline
\end{tabular}

Source: Researcher's Compilation from descriptive statistics (2017).

$\mathrm{TTAX}_{\text {eff }}=$ Total tax revenue effort, $\mathrm{DT}_{\text {eff }}=$ Direct tax revenue effort, $\mathrm{INDT}_{\text {eff }}=$ Indirect tax revenue effort, $\mathrm{NOT}_{\text {eff }}=$ Non-oil tax revenue effort, AGRICSP $_{t}=$ Agricultural sector Productivity, MANSP $_{\mathrm{t}}=$ Manufacturing sector Productivity, TOURSP $\mathrm{T}_{\mathrm{t}}=$ Tourism sector productivity, TELCOMSP $_{\mathrm{t}}=$ Telecommunications sector Productivity, $\mathrm{CAPFR}_{\mathrm{t}}=$ Capital flight, TOPEN $_{\mathrm{t}}=$ Trade Openness, $\mathrm{HCD}_{\mathrm{t}}=$ Human capital development

Table 2 presents the descriptive statistics. However what is of importance to us here is the Jarque-Berra coefficient. The Jarque-Berra coefficients in the summary statistics shows the degree of normality, and hence the heterogeneity of the data series. It is expected that most of the data in a time series estimation procedure are normally distributed in order to avoid structural breaks effects in the estimation. The J-B values for the variables show that they all pass the test of normality because there probabilities are all less than 0.05 . These results indicate that the assumption of normality in the data can be accepted for the aforementioned variables. The implication of this is that the time series are normally distributed and the data is suitable for time series analysis.

\subsection{Unit Root Analysis}

The Augmented Dickey Fuller (ADF) test was employed in order to analyze the unit roots. The results are presented in levels and first difference. This choice of presentation allowed for a determination of result, in comparative terms, of the unit root among the time series and also to obtain more robust results. 
Table 3. Augmented Dicky-Fuller (ADF) unit root test for variables in levels

\begin{tabular}{llll}
\hline VARIABLE & ADF Test Statistic & 95\% Critical ADF Value & Remark \\
\hline TTAX $_{\text {eff }}$ & -1.17 & -2.95 & Non-Stationary \\
DT $_{\text {eff }}$ & -1.23 & -2.95 & Non-stationary \\
INDT $_{\text {eff }}$ & -0.49 & -2.95 & Non-stationary \\
NOT $_{\text {eff }}$ & -0.69 & -2.95 & Non-Stationary \\
AGRICSP $_{\text {MANSP }}$ & -2.01 & -2.95 & Non-stationary \\
TELECOMSP & -1.77 & -2.95 & Non-Stationary \\
TOURSP & -0.08 & -2.95 & Non-stationary \\
CAPFR & 1.9 & -2.95 & Non-Stationary \\
TOPEN & -1.41 & -2.95 & Non-stationary \\
HCD & -1.88 & -2.95 & Non-Stationary \\
\hline
\end{tabular}

Source: Researcher's compilation from E-views 9 (2017).

Table 3 presents results of ADF test in levels without taking into consideration the trend in variables. This was allowed because an explicit test of the trending pattern of the time series was not carried out. Given the result, the ADF test statistic for each of the variables is shown in the second column, while the 95\% critical ADF value is shown in the third column. The result indicates that all the variables possess ADF values that are less than the 95\% critical $\mathrm{ADF}$ value (in absolute values) of 2.95. A critical look at the variables at levels, the result is as follows; $\left.\operatorname{TTAX}_{\text {eff }}(\mathrm{ADF}=-1.17), \mathrm{DT}_{\text {eff }}(\mathrm{ADF}=-1.23), \mathrm{INDT}_{\text {eff }}(\mathrm{ADF}=-0.49), \mathrm{NOT}_{\text {eff }}(\mathrm{ADF}=-0.69), \mathrm{AGRICSP} \mathrm{ADF}=-2.01\right)$, MANSP(ADF $=$-1.77),TELECOMSP(ADF $=-0.08), \quad$ TOURSP(ADF $=1.9), \quad$ CAPFR(ADF $=\quad-1.41)$, TOPEN(ADF=-1.88), $\mathrm{HCD}(\mathrm{ADF}=-1.71)$. The implication of this is that the time series are non-stationary in their levels. In order words, the variables are time-dependent.

Box and Henkins (1978) had argued that non stationary time series in levels may be made stationary by taking their first difference. A given series is said to be integrated of order $d$ (denoted $I(d)$ ) if it attains stationarity after differencing $d$ times. If the series is $I(1)$ it is deemed to have a unit root. This situation arises if the first difference of the series is $I(0)$. We take the first differences of the respective variables and perform the unit root test on each of the resultant time series.

Table 4. Unit root test for variables in first difference

\begin{tabular}{|c|c|c|c|}
\hline VARIABLE & ADF Test Statistic & $95 \%$ Critical ADF Value & Remark \\
\hline$\Delta$ TTAX $_{\text {eff }}$ & -8.91 & -2.95 & Stationary \\
\hline$\Delta \mathbf{D T}_{\text {eff }}$ & -6.88 & -2.95 & Stationary \\
\hline$\Delta \mathrm{INDT}_{\text {eff }}$ & -6.19 & -2.95 & Stationary \\
\hline$\Delta \mathrm{NOT}_{\text {eff }}$ & -5.08 & -2.95 & Stationary \\
\hline$\triangle A G R I C S P$ & -6.51 & -2.95 & Stationary \\
\hline DMANSP & -6.25 & -2.95 & Stationary \\
\hline$\triangle T E L E C O M S P$ & -5.65 & -2.95 & Stationary \\
\hline$\triangle T$ TOURSP & -4.39 & -2.95 & Stationary \\
\hline$\triangle C A P F R$ & -4.28 & -2.95 & Stationary \\
\hline$\triangle T$ TOPEN & -7.47 & -2.95 & Stationary \\
\hline$\triangle H C D$ & -3.93 & -2.95 & Stationary \\
\hline
\end{tabular}

Source: Researcher's Compilation from E-views 9 (2017).

The result of the unit root test on these variables at first differences is reported in Table 4 From the result, it is seen that the ADF test statistic for each of the variables is greater than the 95\% critical ADF values (in absolute 
values).Examining the results we have that $\mathrm{TTAX}_{\text {eff }}(\mathrm{ADF}=-8.91), \mathrm{DT}_{\text {eff }}(\mathrm{ADF}=-6.88), \mathrm{INDT}_{\text {eff }}(\mathrm{ADF}=-6.19)$, $\mathrm{NOT}_{\text {eff }}(\mathrm{ADF}=-5.08), \quad$ AGRICSP(ADF $\left.=-6.51\right), \quad$ MANSP(ADF= -6.25), TELECOMSP(ADF $\left.=-5.65\right)$, TOURSP $(A D F=-4.39), \mathrm{CAPFR}(\mathrm{ADF}=-4.28), \mathrm{TOPEN}(\mathrm{ADF}=-7.477), \mathrm{HCD}(\mathrm{ADF}=-3.93)$. With these result, these variables are adjudged to be stationary. Thus, we accept the hypothesis that the variables possess unit roots. Indeed, the variables are integrated of order one (i.e. I [1]).

\subsection{Multicollinearity Test}

Since the regressor's used in the empirical models in the study are numerous, the outcomes of the coefficient estimates may measure the same effects. To be certain about the avoidance of this error, the multicollinearity tests is conducted on the models to ensure that the explanatory variables are not excessively collinear. It should be noted that high collinearity tends to amplify the standard errors of the estimates and render the reliability of the estimated model quite low.

Table 5. Variance inflation factor (VIF)

\begin{tabular}{|c|c|c|c|c|}
\hline Variable & Total tax effort & Direct tax & Indirect tax & Non-oil tax \\
\hline LTTAX $_{\text {eff }}(-1)$ & 0.01 & 0.02 & 0.04 & 0.02 \\
\hline LAGRICSP & 7.31 & 3.88 & 2.24 & 0.32 \\
\hline LAGRICSP(-1) & 5.71 & 5.99 & 3.15 & 0.32 \\
\hline LAGRICSP(-2) & 5.26 & 4.12 & 2.39 & 0.47 \\
\hline LAGRICSP(-3) & -- & 1.22 & 0.61 & -- \\
\hline LMANSP & 0.51 & 0.78 & 0.32 & 0.15 \\
\hline LMANSP(-1) & 0.45 & 0.35 & 0.17 & 0.20 \\
\hline LMANSP(-2) & 0.42 & 0.37 & 0.31 & 0.16 \\
\hline LMANSP(-3) & 0.62 & 0.70 & 0.33 & -- \\
\hline LTOURSP & 1.00 & 0.47 & 0.32 & 0.10 \\
\hline LTOURSP(-1) & 0.15 & 0.21 & 0.11 & -- \\
\hline LTOURSP(-2) & 0.10 & 0.08 & 0.04 & -- \\
\hline LTOURSP(-3) & 0.10 & -- & 0.04 & -- \\
\hline LTELECOMSP & 0.01 & 0.02 & 0.01 & -- \\
\hline LTELECOMSP(-1) & 0.23 & 0.13 & 0.07 & 0.06 \\
\hline LTELECOMSP(-2) & 0.16 & 0.17 & 0.09 & 0.00 \\
\hline LTELECOMSP(-3) & 0.38 & -- & 0.13 & -- \\
\hline LTOPENSP & 0.03 & 0.03 & 0.02 & 0.02 \\
\hline LTOPENSP(-1) & 0.03 & 0.06 & -- & 0.03 \\
\hline LTOPENSP(-2) & 0.04 & 0.04 & -- & -- \\
\hline LTOPENSP(-3) & 0.04 & 0.02 & -- & -- \\
\hline LHCDSP & 1.16 & 2.63 & 1.08 & 0.46 \\
\hline $\operatorname{LHCDSP}(-1)$ & 1.48 & 2.25 & 0.64 & -- \\
\hline $\operatorname{LHCDSP}(-2)$ & 2.46 & 2.71 & 1.09 & -- \\
\hline $\operatorname{LHCDSP}(-3)$ & 2.18 & 2.64 & 0.58 & -- \\
\hline CAPFRSP & 0.00 & 0.00 & 0.00 & 0.00 \\
\hline CAPFRSP(-1) & -- & 0.00 & 0.00 & -- \\
\hline CAPFRSP(-2) & -- & 0.00 & 0.00 & -- \\
\hline CAPFRSP(-3) & -- & 0.00 & 0.00 & -- \\
\hline
\end{tabular}

Source: Researcher's compilation from E-views 9 (2017). 
In Table 5 the result of the multicollinearity tests for each of the Models was presented. In the result, only the coefficient variances inflation factors (VIF) which are the components that amplify multicollinearity, were reported. From the results, it could be seen that the variance inflation factors (VIF) for each of the variables were quite low for each of the equations. Indeed, the values for each variable was less than 10, thus implying that there was no form of multicollinearity among the variables of the model, even in the short run. And as opined by Marquardt (1970), a VIF greater than 10 showed serious multicollinearity. Also Hair, Anderson, Tatham and Black (1995) opined that a VIF of less than 10 was an indication of inconsequential collinearity. Therefore, the estimates from the regression results are effective for drawing conclusion

\subsection{Autoregressive Distributed Lag (ARDL) Analysis and Discussion of Findings}

It is instructive that the ARDL for long run relationship shows that the selected determinant factors actually moved together with tax revenue effort overtime in this study. The results for the long run equations, based on the co-integrating form from the ARDL modeling procedure, are presented. The long run estimates are obtained from the co-integration form and thus, do not possess diagnostic indicators.

Table 6. Long run determinants of total tax revenue effort

\begin{tabular}{lclllll}
\hline Variable & Coefficient & Prob. & Coeff. & Prob. & Coeff. & Prob. \\
\hline LAGRICSP & 2.41 & 0.09 & 6.73 & 0.00 & -- & -- \\
LMANSP & -2.18 & 0.01 & -1.78 & 0.01 & -- & -- \\
LTOURSP & 2.32 & 0.04 & 0.29 & 0.65 & -- & -- \\
LTELECOMSP & -0.47 & 0.18 & -1.05 & 0.00 & -- & -- \\
LTOPEN & 1.14 & 0.01 & -- & -- & 3.03 & 0.00 \\
LHCD & 6.45 & 0.00 & - & - & 6.36 & 0.03 \\
CAPFR & 0.00 & 0.25 & -- & -- & 0.001 & 0.82 \\
C & 12.7 & 0.26 & -33.5 & 0.00 & -23.6 & 0.02 \\
\hline
\end{tabular}

\section{Source: Researcher's compilation from E-views 9 (2017).}

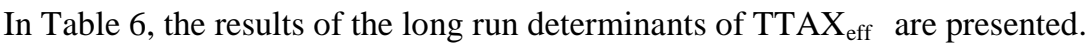

In the result, it can be seen that the coefficients of AGRICSP which is (2.41) is now positive as against the negative outcome for the short run results. The coefficient is only significant at the $10 \%$ level, although the robustness result shows that the significance can be as high as $1 \%$ in the long run. This result implies that any sustained rise in AGRICSP will lead to increase in TTAX $_{\text {eff }}$ in the long run. The short term impact may be negative, but if the increase in the sector output can be sustained, it will eventually cause TTAX $_{\text {eff }}$ to rise in the country. Conversely, MANSP has a negative coefficient (-2.18) which is significant at the 5\% level. This shows that over time, any

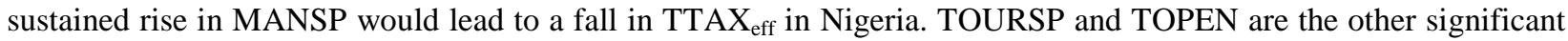

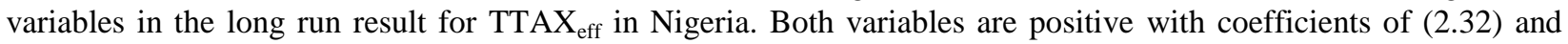
(1.14) which indicate that in the long run, expansion in tourism sector and trade openness tends to increase TTAX $_{\text {eff }}$ in the country. For the second robustness check result, HCD also has a significant positive coefficient at the 5\% level. This shows that development of human capital tends to provide long term tax benefits in Nigeria.

Table 7. Long run determinants of direct tax revenue effort

\begin{tabular}{lrlclll}
\hline Variable & Coeff. & Prob. & Coeff. & Prob. & Coeff. & Prob. \\
\hline LAGRICSP & 8.67 & 0.00 & 6.54 & 0.00 & -- & -- \\
LMANSP & 0.28 & 0.47 & -1.67 & 0.04 & -- & -- \\
LTOURSP & -1.54 & 0.06 & -0.21 & 0.75 & -- & -- \\
LTELECOMSP & -0.85 & 0.00 & -0.67 & 0.04 & -- & -- \\
LTOPEN & -0.79 & 0.07 & & & 2.77 & 0.00 \\
LHCD & 6.07 & 0.01 & & & 4.06 & 0.03 \\
CAPFR & -0.00 & 0.02 & & & 0.001 & 0.23 \\
C & -37.1 & 0.00 & -32.7 & 0.00 & -15.9 & 0.02 \\
\hline
\end{tabular}

Source: Researcher's Compilation from E-views 9 (2017). 
The result for long run determinants of $\mathrm{DT}_{\text {eff }}$ Nigeria is presented in Table 7. From the result, we can see that AGRICSP with a coefficient of (8.67) has a significant and positive impact on DT $_{\text {eff }}$ in the long run. MANSP coefficient fails the significance test at the 5\% level, suggesting that MANSP does not lead to DT eff $_{\text {expansion in }}$ Nigeria over time. TOURSP fails the test at the 5\% level while that of TELECOMSP passes the test at the $1 \%$ level.

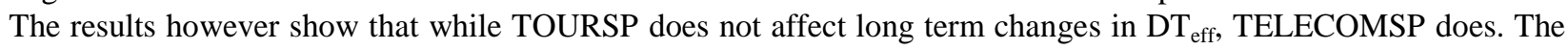
effect is negative, and indicates that when the telecommunication sector grows, less direct tax will be collected in the country. TOPEN coefficient fails the significance test that of HCD is positive and significant while that of CAPFR is positive and significant. This means that human capital development tends to inhibit direct tax effort over time. The more developed the human capital is, the less capacity for revenues in terms of direct taxes in Nigeria. Capital flight shows a negative sign, suggesting that a sustained increase in capital flight could cause less $\mathrm{DT}_{\text {eff }}$ in Nigeria.

Table 8. Long run determinants of indirect tax revenue effort

\begin{tabular}{lrlllll}
\hline Variable & Coeff. & Prob. & Coeff. & Prob. & Coeff. & Prob. \\
\hline LAGRICSP & 7.30 & 0.01 & 7.18 & 0 & -- & -- \\
LMANSP & -0.73 & 0.51 & 1.40 & 0.29 & -- & -- \\
LTOURSP & 1.12 & 0.51 & -0.32 & 0.63 & -- & -- \\
LTELECOMSP & -2.21 & 0.03 & -1.35 & 0.00 & -- & -- \\
LTOPEN & 1.11 & 0.08 & -- & -- & 3.40 & 0 \\
LHCD & 14.52 & 0.19 & -- & -- & 6.15 & 0 \\
CAPFR & 0.00 & 0.17 & -- & -- & 0.001 & 0.04 \\
C & -96.6 & 0.06 & -58.6 & 0 & -24.1 & 0 \\
\hline
\end{tabular}

Source: Researcher's Compilation from E-views 9 (2017).

In Table 8, the long run behaviour of INDT $_{\text {eff }}$ in the face of changes in the determinant variables is reported. The coefficient of AGRICSP (7.30) is positive and passes the significance test at the 5\% level. This suggests that agriculture tends to lead to increases in indirect taxes in the long run. The coefficient of MANSP fails the significance test at the 5\% level, implying that MANSP is not a strong instrument for stimulating long run expansion of the INDT $_{\text {eff }}$ in Nigeria. TOURSP fails the significance test at the 5\% level, while TELECOMSP with a coefficient of (-2.21) is significant but negative. Apparently, TELECOMSP tends to depress INDT $_{\text {eff }}$ in the country over time. TOPEN and HCD both fail the test at the 5\% level, indicating that over time, these factors do not explain the pattern of movement of INDT eff in the country.

Table 9. Long run determinants of non-oil tax revenue effort $\left(\mathrm{NOT}_{\text {eff }}\right)$

\begin{tabular}{lclllll}
\hline Variable & Coeff. & Prob. & Coeff. & Prob. & Coeff. & Prob. \\
\hline LAGRICSP & 1.97 & 0.37 & 10.62 & 0.38 & -- & -- \\
LMANSP & -7.37 & 0.00 & 17.48 & 0.68 & -- & -- \\
LTOURSP & 4.23 & 0.03 & 16.38 & 0.64 & -- & -- \\
LTELECOMSP & -0.10 & 0.71 & 0.87 & 0.81 & -- & -- \\
LTOPEN & 1.67 & 0.03 & -- & -- & 3.81 & 0.00 \\
LHCD & -1.62 & 0.56 & -- & -- & 5.55 & 0.00 \\
CAPFR & -0.001 & 0.02 & -- & -- & 0.00 & 0.09 \\
C & 26.3 & 0.21 & 144 & 0.56 & -23.3 & 0.00 \\
\hline
\end{tabular}

Source: Researcher's Compilation from E-views 9 (2017).

Note: *, **, *** denote significance at 10, 5 and 1 percent level respectively.

The long run results for non-oil tax revenue effort are presented in Table 4.8. In the result, it can be seen that the coefficients of AGRICSP is now positive as against the negative outcome for the short run results. The coefficient however fails the significance test at the 5\% level, suggesting that $\mathrm{NOT}_{\text {eff }}$ in the long run is not explained by 
AGRICSP. MANSP has a negative coefficient of (-7.37) which is significant. This shows that over time, any

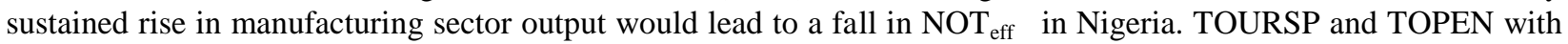
coefficients of (4.23) and (1.67) are the other significant variables in the long run result for $\mathrm{NOT}_{\text {eff }}$ in Nigeria. Both variables are positive and indicate that in the long run, expansion in TOURSP and TOPEN tends to increase NOT $_{\text {eff }}$ in the country. CAPFR also has a significant negative coefficient in the results.

The study revealed that Agricultural sector productivity (AGRICSP) is statistically positively significant. This suggests that AGRICSP has a significant influence on tax revenue effort in Nigeria. The implication is that AGRICSP is a strong determinant of tax revenue effort in Nigeria. The positive coefficient of the result of AGRICSP supports our apriori expectation. This is positive significant relationship is consistent with the findings of Murunga, Muritthi and Kiiru (2016), Ahsan and Wu (2005) who found a positive and significant relationship between tax revenue effort and AGRICSP but negates the findings of Gaalya (2015) and Brun and Diakite (2016) whose researches found a significant negative relationship between AGRICSP and tax revenue effort. The result also negates the findings of Mahdavi (2008) who found a positive and insignificant relationship between AGRICSP and tax revenue effort. This result is a deviation from the normal given that agricultural sector activity in Nigeria is low. However this can be so given the fact that the country in recent years has experienced a drop in oil based revenue and is now really focused greatly on diversifying the economy and agriculture is one of its main focuses.

The study also observed that manufacturing sector productivity (MANSP) appears to have a negative influence on tax revenue effort and is statistically significant. Although the results indicate that MANSP is a strong determinant, however it is negative in nature. The implication of this is that MANSP and tax revenue effort move in opposite directions in Nigeria, and thus tax revenue from manufacturing activities in Nigeria tends to diminish consistently overtime. This can be said to be as a result of the poor industrialization of the country as well as the lack of expansion activities in the sector. The results is in tandem with the findings of Teera and Hudson (2004) who found a significant negative relationship between tax revenue effort and manufacturing sector productivity in middle income countries. It however negates the findings of Babyenda and Klege (2014), Piancastelli, (2001), Oyetunji (2012) whose studies found that there was a significant and positive relationship between MANSP and tax revenue effort.

The study found that there exist a positive and statistically significant relationship between tourism sector productivity (TOURSP) and tax revenue effort in Nigeria. The results suggest that tourism sector productivity is a strong determinant of tax revenue effort in Nigeria. This means that this sector is a veritable avenue for stimulating tax revenue in Nigeria. The result is in tandem with the study of Ahmed and Mohammed (2010), Murunga, Muritthi and Kiiru (2016) but negates the study of Bothole (2010) whose studies found a significant and negative relationship between the service sector and tax revenue effort.

The study also observed that Telecommunication sector productivity (TELECOMSP) appears to have a negative influence on tax revenue effort and is statistically significant. Although the results indicate that TELECOMSP is a strong determinant, however it is negative in nature. The result is in tandem with the study of Bothole (2010) but negates of Ahmed and Mohammed (2010), Murunga, Muritthi and Kiiru (2016), whose studies found a significant and positive relationship between the service sector and tax revenue effort.

The study revealed that Capital flight (CAPFR) has a significant negative influence on tax revenue effort in Nigeria. This implies that the illegal removal of financial capital in Nigeria actually has effects on tax revenue in Nigeria. This finding is in tandem with the findings of Uguru (2011) who discovered that capital flight through tax evasion reduces government revenue and does in turn affect tax revenue effort while studying the impact of capital flight on tax paid by some selected multinational corporations in Nigeria. It also in tandem with the finding of Uguru (2016) who found that capital flight has a significant effect on tax revenue as a percentage increase in capital flight leads to a two percent decrease in tax revenue while studying the effect of capital flight on tax revenue in Nigeria.

The study revealed that Trade openness (TOPEN) is statistically positively significant. This suggests that TOPEN has a significant influence on tax revenue effort in Nigeria. The implication is that TOPEN is a strong determinant of tax revenue effort in Nigeria. This means that foreign trade is seen as a strategic tool for raising government tax in Nigeria, thereby implying that more foreign trade would improve tax revenue effort overtime. The findings are in tandem with Brun and Diakité, (2016), Haque (2009), Gaalya (2015), Urhoghide and Asemota (2013), whose research findings indicate that there is a significant positive relationship between trade openness and tax revenue effort. However it negates the findings of Torgler (2004) Rabiei and Balagetabi (2013), who found a significant and negative relationship between trade openness and tax revenue effort.

Lastly, Human capital Development (HCD) was found to be positively related to tax revenue effort. This relationship was also found to statistically significant. The result indicates that HCD exhibits strong positive effects on tax effort 
in Nigeria. This result is in tandem with Mahdavi (2008) who studied the level of composition of tax revenue in 43 developing countries covering a period of 1970 to 2002, and discovered that a higher level of basic education positively affects the sales and excise taxes. He went further to say that improving the literacy rate would ultimately increase tax revenue but it negates the findings of Chaudry and Munir (2010) who while analysing the determinants of low tax revenue in Pakistan discovered that an increase in the literacy rate brings about a decrease in the collected tax revenue.

\section{Conclusion and Recommendations}

In Nigeria today, the mobilization of tax revenue has become an important policy objective. While governments can do little in the short run to change structural determinants of the tax revenue (such as composition of output shares), they can alter other factors that influence tax revenue, such as economic policies, the level of foreign trade, and the quality of human capital development. This study has shown that there are many sectors and factors that can ensure improvement in tax revenue effort both in the short run and in the long run in Nigeria. There is however need to address certain areas in order to consistently ensure better performance of tax effort in the country. This can be done by enforcing tax and customs administrations, reducing tax exemptions (especially in the areas of manufacturing), and fighting fraud and corruption.

Finally, there must be consideration for the realistic extent to which improvement in revenue ratios that can be expected to be achieved in Nigeria, given the level of development of the economy. The heavily agricultural and informal character that has characterized the economy also renders tax revenue effort quite cumbersome in the country. Indeed, optimizing tax mobilization and carrying out reforms can be achieved only when there is a strong political will and leadership to adopt the necessary measures. The study therefore recommends that because of

The dynamically divergent impacts of many of the factors on tax revenue effort there is therefore the need for tax administrators to be cautious about the pattern of procedures in administering different sectors of the Nigerian economy. Tax rules aimed at certain sectors of the economy must take into cognizance the long run implications. Indeed, rules that are too narrowly applied in certain sectors may eventually become inimical for overall tax revenue effort in the country over time.

However the recommendations provided were made and should be implemented on the basis of the given timeframe restriction of 1998 to 2015 and measurement of some variables, such as the human capital development and capital flight which in our opinion could have been measured differently by other researchers.

Based on the foregoing, it is suggested for future studies that other sectors of the economy can be taken up.Besides, additional variables, such as the number of registered tax payers, be included in a the model of a future research to expand the scope. Finally, and perhaps, other measurements can be used for the same variable instead of the measurements used in this study to see the behaviour, relationship and significance of the variable(s)

\section{References}

African Development Bank (AFDB) \& Global Financial Integrity (GFI). (2013). Illicit Financial Flows and the Problem of Net Resource Transfers from Africa: 1980-2009. Washington, DC and Tunis.

Ahmed, Q.M., \& Mohammed, S.D. (2010). Determinants of tax buoyancy: Empirical evidence from developing countries. European Journal of Social Science, 13(3), 408-414.

Ajayi, I.S. (1997). An analysis of external debt and capital flight in the severely indebted low-income countries in Sub-Saharan Africa. IMF, Working Study WP/97/68. https://doi.org/10.5089/9781451961119.001

Andreoni, J., Erard, B. , \& Feinstein, J. (1998). Tax compliance. Journal of Economic Literature, 36 (2), 818- 860.

Ayenew, W. (2016). Determinants of tax revenue in Ethiopia : Johansen co-integration approach).International Journal of Business, Economics and Management, 3(6), 69-84. https://doi.org/10.18488/journal.62/2016.3.6/62.6.69.84

Babyenda, P., \& Klege, R.A. (2014). East African Community (EAC) and Uganda's tax revenue. Research Journal of Finance and Accounting, 5(10), 138-144.

Bird, R. M., Martínez-Vásquez, J., \& Torgler, B. (2004). Societal institutions and tax effort in developing countries. Andrew Young School of Policy Studies, Georgia State University. Working Study 04-06.

Bird, R. M., Martinez-Vasquez, J., \&Torgler, B. (2008). Tax effort in developing countries and high-income countries: The impact of corruption, voice and accountability. Economic Analysis and Policy, 38, 55-71. https://doi.org/10.1016/S0313-5926(08)50006-3 
Botlhole, T.D. (2010). Tax effort and determinants of tax ratio in sub-Saharan Africa. Study presented at International Conference on Applied Economics, 101-113.

Brun J.-F., \& Diakité, M. (2016). Tax potential and tax effort: An empirical estimation for non-resource tax revenue and VAT's Revenue. Études et Documents, 10, CERDI 2-64. Retrieved from cerdi.org/uploads/ed/2016/2016.10v

Central Bank of Nigeria Statistical Bulletin (2013). Retrieved from https://www.cbn.gov.ng/.../2013/.../memo_q4\%202012\%20quarterly\%20statistical\%

Central Bank Statistical of Nigeria Bulletin (2014). Retrieved from https://www.cbn.gov.ng/../2015/../2014\%20Statistical\%20Bulletin_Section\%20D

Chaudhry, I.M., \& Munir F. (2010). Determinants of low taxes in Pakistan. Pakistan Journal of Social Sciences,30 (2), 439-452.

Davoodi, H.R., \& Grigorian, D.A. (2007). Tax potential and tax effort: A cross-country analysis of Armenia's stubbornly low tax collection. IMF staff Study.

Eltony, M. (2002). Thedeterminants of tax effort in Arab countries. Working Study Series from Arab Planning Institute - Kuwait.

Eze, O. R., \& Ogiji, F. O. (2013). Impact of fiscal policy on the manufacturing sector output in Nigeria: an error correction analysis. International Journal of Business and Management Revie, 1(3), 35-55.

Federal Inland Revenue Service Handbook (2012). Retrieved from https://www.firs.gov.ng/.

Federal Inland Revenue Service ( 2013). Retrieved from https://www.firs.gov.ng/.

Federal Inland Revenue Service (2014). Annual summary of collected tax in Nigeria. Available from www.firs.gov.ng.

Gaalya, M.S. (2015). Trade liberalization and tax performance in Uganda. Modern Economy, 6, 228-244. https://doi.org/10.4236/me.2015.62021

Hair, J. F. Jr., Anderson, R. E., Tatham, R. L. ,\& Black, W. C. (1995). Multivariate data analysis (3rd edn) New York: Macmillan.

Henry, J. S. (2012). The price of offshore revisited. London: Tax Justice Network.

Hinricks, H. H. (1966). A general theory of tax structure change during economic development. Law School of Harvard University, Cambridge.

Isu, H.O. (2002). Capital flight and Nigeria's development: An Analytical Review. J. Fin. Banking and Investment, 2 (2), 31-42.

Karagoz, K. (2013). Determinants of Tax Revenue: Does sectorial composition matter? Journal of Finance, Accounting and Management,4(2) 50-63.

Langford, B., \& Ohlenburg, T. (2015). Tax revenue potential and effort: An empirical investigation. International Growth Centre Working Study Version: 3 August 2015

Le, M. T., Moreno-Dodson, B., \& Bayraktar, N. (2012). Tax capacity and tax effort: Extended cross-country analysis from 1994 to 2009. World Bank Policy Research Study. https://doi.org/10.1596/1813-9450-6252

Lotz, J.R., \& Morss, E. R. (1967). Measuring 'tax effort' in developing countries. International Monetary Staff Studys, 14(3), 479-497.

Lotz, J.R. \& Morss, E.R. (1970) A theory of tax level determinants for developing countries. Economic Development and Cultural Change, 18, 328-341. https://doi.org/10.1086/450436

Mahdavi, S. (2008). The level and composition of tax revenue in developing countries: Evidence from unbalanced panel data. International Review of Economics and Finance, 17, 607-617. https://doi.org/10.1016/j.iref.2008.01.001

Mathieson, A. , \& Wall, G. (1982). Tourism: Economic, Physical and Social Impacts. New York: Longman House.

Marquardt, D. W. (1970). Generalized inverses, ridge regression, biased linear estimation, and non linear estimation. Technometrics, 12 , 591-256. https://doi.org/10.2307/1267205 
Muthui, J.N.,Akim, K.,Mdoe, J.K., \& Thuku, G.K.(2015) Tax effort differentials between Kenya and Nigeria (2002-2012). International Journal of Business and Social Science, 6(4), 142-146.

Murunga,J., Muritthi, M., \& Kiiru, J. (2016). Tax effort and determinants of tax ratio in Kenya. European Journal of Economics, Law and Politics, 3(2), 24 -36. https://doi.org/10.19044/elp.v3no2a2

National Bureau of Statistics. (2014). Annual abstracts of statistics. Retrieved from https://nigerianstat.gov.ng/elibrary

National Bureau of Statistics. (2015). Annual abstracts of statistics. Retrieved from https://nigerianstat.gov.ng/elibrary

Nigerian Communication Commission. (2014). Percentage contribution of telecoms to GDP 2001-March 2013. Retrieved from https://www.ncc.gov.ng/.../764-the-role-of-telecoms-sector-to-diversification-of-the-ni

Ndiaye, M.B.O.,\& Korsu, R.D. (2011). Tax effort in ECOWAS countries. West African Monetary Agency, Mimeo.

Ndikumana, L., \& Boyce, J. K. (2011). Africa's odious debts: How foreign loans and capital flight bled a continent. London: Zed Books.

Okafor, R.G.(2012). Tax revenue generation and Nigerian economic development. European Journal of Business and Management. 4(19). 49 - 56.

Ogunsanya, S. (2013). How Airtel became Nigeria's leading telecoms company. Retrieved on 22nd of March 2014 from www.topcelebritiesng.com/how-airtel-became-nigerias-leading-telecoms-company-segun-ognsanya.

Pesaran,H.M.,Shim,Y., \& Smith,R. (1996). Testing the existence of a long-run relationship.DAE working paper series no.9622. Department of Applied Economics, University of Cambridge.

Pesaran,H.M.,Shim,Y., \& Smith,R. (2001). Bounds testing approaches to the analysis of level relationships. Journal of Applied Econometrices, 16, 289-326. https://doi.org/10.1002/jae.616

Piancastelli, M. (2001). Measuring the tax effort of developed and developing countries. Cross country panel data analysis 1985-1995. Discussion Study, IPEA, Rio de Janeiro, September.

Rabiei, M. \& Balagetabi, F.E (2013). Estimation of tax capacity and effort and oil revenue. Research Journal of Applied Sciences, Engineering and Technology 6(10), 1799-1804. https://doi.org/10.19026/rjaset.6.3906

Rajaram, A. (1994). Tariff and tax reforms do World Bank recommendations integrate revenue and protection objectives? Econ. Stud. Quart., 45, 321-338

Saheed, Z.S., \& Ayodeji, S. (2012). Impact of capital flight on exchange rate and economic Growth in Nigeria. International Journal of Humanities Social Science, 2(13).

Stotsky, J., \& WoldeMariam, A. (1997). Tax effort in sub-saharan Africa. IMF staff Study, 97/107, Washington DC: International Monetary Fund.

Teera, J.M. \& Hudson, J. (2004). Tax performance: A comparative study. Journal of International Development, 16(6), 785-802. https://doi.org/10.1002/jid.1113

Uguru, L. C. (2011). Impact of capital flight on corporate performance in Nigeria. Nigerian Journal of Business, 5(1), $83-92$.

Uguru, L. C. (2016). On the tax implication of capital flight: Evidence from Nigeria. Journal of Research in Economics and International Finance, 5(1), 1-7.

Urhoghide, R.O., \& Asemota, G.O. (2013). Determinants of tax revenue effort; Empirical evidence from Nigeria. Culture and religion review journal, 243-65.

World Development Indicator. (2014). World Development Indicators. Washington, DC: World Bank

World Development Indicator. (2015). World Development Indicators. Washington, DC: World Bank

World Travel and Tourism Council. (2014).The authority on world travel and tourism: Travel and tourism economic impact on Nigeria.

World Tourism Organisation (WTO). (1996). Tourism: 2010 Vision Madrid: WTO. 